\title{
KORELASI POWER OTOT TUNGKAI DAN KOORDINASI MATA KAKI TERHADAP SHOOTING PADA PERMAINAN SEPAK BOLA PERSILA BIMA
}

\author{
Sukarman \\ DOSEN IKIP Mataram \\ Email : sukarman84@yahoo.com
}

\begin{abstract}
In playing football, players still had less ability in shooting so the researcher formulated the problem as follows. is there correlation between limb muscle power power and foot eye coordination toward the shooting results in football on player of Persila Bima. In accordance with the problem, the purpose of the research is to find out whether or not there is a correlation between limb muscle power and foot eye coordination toward the shooting result in football on players of Persila Bima. This kind of research is included into qualitative research design by product moment correlation. The sample of this research were the players of Persila Bima with the number of sample of 20 players by population study. The data analysis used is multiple correlation analysis by $5 \%$ significance level. The results of the data analysis obtained that $\mathrm{R}=0.835$ (R-score $=0.835>\mathrm{R}$-table $=0.444)$. It can concluded that there is correlation between limb muscle power and foot eye coordination toward the shooting result in football on players of Persila.
\end{abstract}

\begin{abstract}
Abstrak: Dalam bermain sepak bola para pemain masih kurang memiliki kemampuan dalam melakukan shooting sehingga berdasarkan permasalahan tersebut peneliti merumuskan permasalahan sebagai berikut. apakah ada korelasi power otot tungkai dan koordinasi mata kaki terhadap hasil shooting dalam permainan sepak bola pada pemain Persila Bima. Sesuai dengan rumusan masalah tersebut maka tujuan penelitian adalah Ingin Mengetahui apakah ada hubungan power otot tungkai dan koordinasi mata kaki terhadap shooting dalam permainan sepak bola pada pemain Persila Bima. Penelitian ini termasuk jenis penelitian kuantitativ dengan rancangan penelitian korelasi product moment. Sampel penelitian ini adalah sebagian pemain persila bima. dengan jumlah sample 20 pemain atau menggunakan tekhnik studi populasi. Tekhnik analisis data yang digunakan adalah teknik analisis korelasi ganda pada taraf signifikan 5\% berdasarkan dari hasil analisis data. Menunjukan hasil penelitian terdapat korelasi yang signifikan antara power otot tungkai dan koordinasi mata kaki terhadap shooting pada pemain Persila Bima tahun 2018, terbukti $\mathrm{R}$-hitung $=0,835$ (R-hitung=0,835 $>\mathrm{R}$-tabel=0,444).maka dapat di simpulkan bahwa ada hubungan power otot tungkai dan koordinasi mata kaki terhadap hasil shooting pada pemain persila Bima.
\end{abstract}

\section{Kata kunci : Power Otot Tungkai dan Koordinasi Mata Kaki Terhadap Shooting}

\section{PENDAHULUAN}

Indonesia termasuk negara yang memiliki banyak klub dan sekolah sepak bola.Dihampir setiap daerah terdapat sekolah sepak bola, termasuk wilayah Bima, Nusa Tenggara Barat. Lebih khususnya lagi di Kecamatan Bolo terdapat club sepak bola bernama Persila Bima. Pesila Bima terbuka untuk remaja usia SMA hingga remaja, mengadakan latihan setiap tiga kali dalam minggu yaitu selasa dan jumat dan minggu dengan total pemain total jumlah pemain kurang lebih 20 pemain.

Banyak pemain yang masuk ke club Persila Bima menunjukan antusiasme warga masyarakat terhadap sepak bola. Tetapi antusiasme warga tersebut tidak di iringi dengan kemampuan power otot tungkai yang dimiliki oleh pemain di club Persila Bima. Hal ini terbukti dengan tidak adanya kemampuan shooting yang di milki para pemain di club Persila Bima.

Dalam olahraga sepak bola ada beberapa teknik dasar yang harus di pelajari untuk mencapai hasil yang baik. Menurut Sucipto, dkk (2000:17):

Teknik dasar yang perlu dimiliki oleh pemain sepak bola adalah menendang (kicking), menghentikan (stoping), menggiring (dribbling), menyundul 
(heading), merampas (tackling), lemparan kedalam (throw-in), dan menjaga gawang (goal keeping). Salah satu teknik dasar yang sangat berpengaruh dalam permainan sepak bola adalah menendang (passing dan shooting), shooting merupakan salah satu usaha memindahkan bola dari satu tempat ke tempat yang lain dengan menggunakan kaki atau bagian kaki, seorang pemain sepak bola yang tidak bisa menguasai teknik menendang bola dengan benar, maka tidak mungkin menjadi pesepak bola yang bisa di andalkan.

Dilihat dari perkenaan kaki ke bola, menendang dibedakan menjadi beberapa macam, yaitu menggunakan jarak pendek (short passing), menendang dengan kaki bagian luar (outside), digunakan untuk menggumpan jarak pendek (shortpassing), menendang dengan punggung kaki (instep) digunakan untuk menembak bola ke gawang (shooting at the goal), dan menendang dengan punggung kaki bagian dalam (inside of instep) di gunakan untuk mengumpan jarak jauh (long passing). Dalam menendang bola power otot kaki sangat dibutuhkan sehingga perlu diupayakan meningkatkan latihan terutama latihan power otot tungkai.Untuk menghasilkan shooting yang baik maka perlu adanya kondisi fisik yang baik pula, Kondisi fisik yang digunakan adalah power otot tungkai selain itu koordinasi mata kaki juga sangat di butuh dalam melakukan shooting. power otot tungkai sangat dibutuhkan oleh seorang pemain sepak bola dalam melakukan tendangan (shooting) langsung ke gawang untuk mencetak goal. Peran serta power otot tungkai sangat menentukan, karena power otot tungkai sangat menentukan, karena power otot tungkai yang berfungsi mengayunkan kaki menendang kearah depan dilakukan dengan cepat dan dalam waktu relatife singkat.

Novit, S (2003) melakukan penelitian di Jepara pada Tahun 2013 terhadap 18 pemain klub sepak bola Persilang yang bermain di divisi II Liga Jepara. Hasil penelitian menyebutkan bahwa terdapat pengaruh power otot tungkai terhadap hasil tendangan kearah gawang.Yaitu semakin baik power otot tungkai maka semakin tepat tendangan kearah gawang.
Dengan demikian power otot tungkai merupakan salah satu faktor penting dalam mendukung kesuksesan pemain sepak bola dalam mencetak goal.Tetapi Persila Bima tidak di temukan pola latihan seperti tersebut.Hal ini terbukti dari pengamatan pada saat latihan shooting ke gawang banyak yang melenceng kesamping maupun diatas gawang, padahal mereka memiliki kondisi tubuh yang ideal untuk menendang bola kearah gawang.

Guna mendapatkan hasil shooting yang cepat dankeras di butuhkan faktor kodisi fisik yaitu power otot tungkai .Hal ini di sebabkan bahwa power merupakan faktor yang sangat penting dan diperlukan pada waktu melakukan shooting.Oleh karena itu salah satu prinsip yang paling utama dalam latihan adalah membangun dan meningkatkan kekuatan otot.Selain kekuatan untuk menghasilkan shooting yang baik maka diperlukan koordinasi mata kaki pula. Pemain yang memiliki koordinasi mata kakiyang cukup bagus akan menghasilkan shooting yang akurat dalam setiap kesempatan. Koordinasi mata kaki dengan kemampuan shooting dalam permainan sepak bola perlu dilakukan tes dan pengukuran.Data hasil mengukur tersebut di harapkan dapat menjadikan dasar atau acuan dalam melakukan latihan yang baik dan sungguhsunggguh berdasarkan prinsip-prinsip dasar latihan menuju pencapaian prestasi yang optimal dan mampu dipertahankan sampai pada masa-masa selanjutnya baik persiapan untuk laga tingkat lokal, regional, nasional maupun internasional.

\section{KAJIAN TEORI}

Sepak bola merupakan permainan yang beregu yang masing-masing regu terdiri atas sebelas pemain. Biasanya permainan sepak bola dimainkan dalam dua babak (2 kali 45 menit) dengan waktu istirahat ( 10 menit) di antara dua babak tersebut. Menecetak goal ke gawang merupakan tujua kedua kesebelasan.Suatu kesebelasan di nyatakan sebagai pemenang apabila kesebelasan tersebut dapat memasukan bola ke gawang lawan lebih banyak dan kemasukan bola lebih sedikit jika di bandingkan dengan lawannya.

Teknik dasar sepak bola merupakan bagian olahraga sepakbola yang sangat penting. Berbagai teknik dalam sepakbola 
harus dikuasai oleh setiap pemain agar dalam melakukan gerakan menjadi baik sehingga dapat menguasai bola dengan baik pula. Pemain yang memiliki teknik dasar yang baik dalam mengolah bola, maka pemain tersebut cenderung dapat bermain sepakbola dengan baik pula.

Menurut Sucipto, dkk. (2000: 17), teknik dasar dalam permainan sepak bola adalah sebagai berikut. 1) Menendang (kicking)

Menendang merupakan salah satu karakteristik permainan sepak bola yang paling dominan. Pemain yang memiliki teknik menendang bola dengan baik akan dapat bermain secara efisien. Tujuan menendang bola adalah untuk mengumpan (passing), menembak ke gawang (shooting at the goal), dan menyapu untuk menggagalkan serangan lawan (sweeping). Dilihat dari perkenaan bagian kaki ke bola, menendang dibedakan menjadi beberapa macam, yaitu menendang dengan menggunakan kaki bagian dalam (inside), kaki bagian luar (outside), punggung kaki, dan punggung kaki bagian dalam (insideof theinstep). 2) Menghentikan (stooping)

Merupakan salah satu teknik dasar dalam permainan sepa kbola yang penggunaannya bersamaan dengan teknik menendang bola. Tujuan menghentikan bola untuk mengontrol bola, yang termasuk didalamnya mengatur tempo permainan, mengalihkan laju permainan dan memudahkan untuk passing. Dilihat dari perkenaan bagian badan yang pada umumnya digunakan untuk menghentikan bola adalah kaki, paha dan dada. Bagian kaki yang biasa digunakan untuk menghentikan bola adalah kaki bagian dalam, kaki bagian luar, punggung kaki, dan telapak kaki. 3) Menggiring (dribbling) Pada dasarnya menggiring bola adalah menendang terputusputus atau pelan-pelan. Oleh karena itu, bagian kaki yang dipergunakan dalam menggiring bola sama dengan bagian kaki yang dipergunakan untuk menendang bola. Menggiring bola bertujuan antara lain untuk mendekati jarak ke sasaran, melewati lawan dan menghambat permainan. Beberapa macam menggiring bola, yaitu menggiring bola dengan kaki bagian luar, kaki bagian dalam, dan dengan punggung kaki. 4) Menyundul (heading). Menyundul bola pada hakikatnya memainkan bola dengan kepala. Tujuan menyundul bola dalam permainan sepakbola adalah untuk mengumpan, mencetak goal dan mematahkan serangan lawan/atau membuang bola. Ditinjau dari posisi tubuhnya, menyundul bola dapat dilakukan sambil berdiri, melompat dan sambil meloncat. Banyak goal tercipta dalam permainan sepakbola dari hasil sundulan kepala. Merampas (tackling)

Merampas bola merupakan upaya untuk merebut bola dari penguasaan lawan. Merampas bola bisa dilakukan dengan sambil (standing tackling) berdiri dan sambil meluncur (sliding tackling). Lempar ke Dalam (trowh-in)

Lemparan ke dalam merupakan satusatunya teknik dalam permainan sepakbola yang dimainkan dengan lengan dari luar lapangan permainan. Lemparan ke dalam dapat dilakukan dengan atau tanpa awalan, baik dengan posisi kaki sejajar maupun salah satu di depan.

\section{METODE PENELITIAN}

metode merupakan cara yang akan menentukan berhasil atau tdaknya tujuan yang akan dicapai. Penelitian ini termasuk jenis penelitian korelasional, dengan metode penelitian yang digunakan adalah metode eksperimen. Menurut Suharsimi A (2009:312), penelitian korelasional adalah penelitian untuk menemukan ada tidaknya hubungan dan apabila ada, berapa eratnya hubungan serta berarti tidaknya hubungan.

"Metode merupakan cara utama yang dipergunakan untuk mencapai suatu tujuan, misalnya untuk menguji serangkaiaan hipotesa, dengan mempergunakan teknit dan alat-alat tertentu. Cara utama yang di pergunakan setelah penyelididk memperhitungkan kewajaranya ditinjau dari tujuan penyelidikan serta dari situasi penyelidikan."

Jenis pelitian ini adalah penelitian kuantitatif dengan penedekatan metode eksperimen, yaitu penelitian bertujuan untuk menjelaskan, meringkaskan berbagai kondisi, berbagai situasi atau berbagai variable yang ditimbul di masarakat yang menjadi objek penelitian itu berdasarkan apa yang terjadi. 
Penulis menggunakan desain penelitian dengan mengelompokan variable penelitian sebagai berikut:

1. Variabel bebas ke 1 Power Otot Tungkai (X1)

2. Variabel bebas ke 2 Koordinasi mata kaki (X2)

3. Variabel terikat Shooting ke gawang (Y)

\section{HASIL PENELITIAN}

Berdasarkan hasil analisis yang sudah dilakukan di atas maka dapat ditarik kesimpulan sesuai dengan hipotesis yang diajukan yaitu hipotesis alternatif ( $\mathrm{Ha}$ ) yang berbunyi: Ada korelasi power otot tungkai terhadap shooting pada permainan sepak bola club Persila Bima.

Adapun hasil penelitian dan analisi datanya adalah:

1. Hasil penelitian dan analisis data untuk kelompok latihan passing kontrol aktif segitiga

Dari hasil penelitian dan analisa data yang dilakukan dengan menggunakan rumus statistik menunjukkan bahwa $t$ hasil perhitungan yang diperoleh yaitu 9,146 sedangkan pada $\mathrm{t}$ dengan derajat kebebasan $\mathrm{N}-1=19$ pada taraf signifikan 5\% yaitu 2,093. hal ini menunjukkan bahwa $t$ lebih besar dari t. Dengan demikian, maka hipotesis alternative $(\mathrm{Ha})$ yang diajukan diterima dan hipotesis nol (Ho) ditolak.

Dengan demikian, maka hipotesis alternative (Ha) yang diajukan diterima dan hipotesis nol (Ho) ditolak.Untuk itu bagi kelompok latihan passing kontrol aktif segitiga "Ada Pengaruh latihan passing kontrol aktif segitiga Terhadap Kemampuan passing pada pemain futsal micu fc Tahun 2018.

2. Hasil penelitian dan analisis data untuk kelompok latihan small side games

Dari hasil penelitian dan analisa data yang dilakukan dengan menggunakan rumus statistik menunjukkan bahwa $\mathrm{t}$ hasil perhitungan yang diperoleh yaitu 9,937 sedangkan pada $\mathrm{t}$ dengan derajat kebebasan $\mathrm{N}-1=19$ pada taraf signifikan 5\% yaitu 2,093hal ini menunjukkan bahwa $t$ lebih besar dari t Dengan demikian, maka hipotesis alternative (Ha) yang diajukan diterima dan hipotesis nol (Ho) ditolak.
Dengan demikian, maka hipotesis alternative $(\mathrm{Ha})$ yang diajukan diterima dan hipotesis nol (Ho) ditolak. Hal ini berarti “ Ada Pengaruh Latihan small side games Terhadap Kemampuan passing pada pemain futsal micu fc Tahun 2018.

\section{SIMPULAN}

Berdasarkan analisa data yang sudah dilakukan, dapat diketahui bahwa hubungan power otot tungkai dan koordinasi mata kaki terhadap hasil shooting pada permainan sepak bola Persila Bima tahun 2018 signifikan. 1) Karena $\mathrm{r}$ hitung $<\mathrm{r}$ tabel $(0,884>0,444)$ maka, hubungan power otot tungkai $\left(x_{1}\right)$ dengan hasil shooting (Y) signifikan. 2) Karena $\mathrm{r}$ hitung $<\mathrm{r}$ tabel $(2,198>0,444)$ maka, hubungan antara koordinasi mata kaki $\left(x_{2}\right)$ dengan hasil shooting (Y) signifikan. 3) Karena $\mathrm{r}$ hitung $<\mathrm{r}$ tabel $(1,314>0,444)$ maka, hubungan power otot tungkai $\left(x_{1}\right)$ dengan koordinasi mata kaki $\left(x_{2}\right)$ signifikan.

Dari hasil analisis data menggunakan rumus Korelasi Linier Ganda yang sudah dijelaskan pada bab IV, diketahui bahwa nilai r hitung sebesar 0,835 >r tabel sebesar 0,444. Berdasarkan hasil tersebut dapat disimpulkan bahwa Hipotesis alternatif (Ha) yang menyatakan: "ada hubungan antara power otot tungkai dan koordinasi mata kaki terhadap hasil shooting pada permainan sepak bola Persila Bima tahun 2018" diterima.Artinya power otot tungkai dan koordinasi mata kaki berpengaruh besar terhadap hasil shooting.

\section{SARAN}

Dengan berpedoman pada hasil penelitian ini, peneliti ingin mengemukakan beberapa saran yang diharapkan bermanfaat baik bagi atlet, guru atau pembina olahraga maupun pelatih dalam cabang olahraga sepak bola khususnya. Kepada para guru/pembina untuk lebihmemperhatikan kemampuan dan minat yang dimiliki oleh para siswa agar bisa ditingkatkan melalui latihan yang tekun. Kepada para atlet agar terus berlatih dengan tekun karena faktor tekhnik juga sangat menetukan dalam permainan sepak bola. Kepada para peneliti lain yang berminat untuk melanjutkan penelitian ini, diharapkan dapat lebih memperluas ruang lingkup, variabel dan masalahnya sehingga dapat memperkaya khasanah ilmu pengetahuan, khususnya 
JIME, Vol. 4. No. 1

tentang olahraga permainan dalam kaitannya dengan permainan sepak bola.

\section{REFERENSI}

Sucipto, dkk, 2000. Olahraga Untuk Pelatih, Pembina dan Penggemar.

Jakarta: PT. Sastra Budaya.

Bompa, Tudar A. 1983. Theory and Methodology of Training; The Key of Athletic Peiformance. Dibique. Iowa: Hunt Publishing Company.

Depdikbud. 1991/1992. Olahraga Pilihan Sepakbola. Proyek Pembinaan Tenaga Pendidikan 1972Pedoman

Daniel, Mielke. 2007. Dasar Bermain Sepakbola. Yogyakarta :IntanPermata. Jilidkedua.

Hulfian,Lalu.2015. Tes dan Pengukuran Dikjas . Lotim: Garuda Ilmu. 